\title{
ANALISIS IMPLEMENTASI EARMARKING TAX ATAS PAJAK ROKOK DI KOTA TOMOHON
}

\author{
Filicia Margaretha Ayu Mandagi ${ }^{1}$, Jantje Tinangon², Sonny Pangerapan ${ }^{3}$ \\ ${ }^{1,2,3}$ Fakultas Ekonomi dan Bisnis, Jurusan Akuntansi, Universitas Sam Ratulangi, Jl. Kampus Bahu, Manado, \\ 95115, Indonesia
}

E-mail : filiciamandagi19@gmail.com

\begin{abstract}
Since Indonesia adopted the era of regional autonomy which was formalized on January 1, 2010, earmarking tax or government policy in allocating tax funds began to be implemented in Indonesia. One type of tax allocated for tax funds is cigarette tax. Cigarette tax funds are generated from cigarette excise levied by the central government and collected to regions with the aim of financing public health services.The purpose of this study is to analyze the possibilities that occur when the application of earmarking tax in Tomohon City is carried out and whether it is in accordance with the provisions of Law No. 28/2009 and the Regulation of the Minister of Finance of the Republic of Indonesia Number 102 / PMK / 07/2015 in this case concerning how the amount of profit sharing funds received by the City of Tomohon and how much realization has been achieved. The research method used is descriptive.The research method used is descriptive. Based on the research results obtained show that the City of Tomohon has implemented a cigarette tax earmarking tax that is 50\% for public health services in accordance with Law Number 28 of 2009 and Regulation of the Minister of Finance of the Republic of Indonesia Number 102 /PMK /07/2015.Although in accordance with the regulations, the Tomohon City Government must increase the allocation funds to fund the community's healthy living and law enforcement program, and need to maintain the stability of the realization in order to prevent a decrease in revenue from sharing the cigarette tax.
\end{abstract}

Keywords: earmarking tax; cigarette tax; region tax; realization; tax collection.

\section{PENDAHULUAN}

Berkembangnya suatu negara dipengaruhi oleh salah satu faktor yaitu melalui penerimaan dari sektor pajak yang merupakan sumber pendapatan terbesar negara. Desentralisasi fiskal atau penyerahan kewenangan fiskal dari pemerintah pusat kepada pemerintah daerah merupakan sistem pemeritah yang disentralisasi diwujudkan dengan sistem otonomi daerah yang tadinya harus diputuskan pada pemerintah pusat kini dapat diputuskan di tingkat pemerintah daerah. Pada sistem ini mempermudah untuk pemerintah daerah mengambil keputusan bagi kemajuan daerahnya sendiri.Sejak Indonesia mulai memberlakukan era otonomi daerah yang diresmikan pada tanggal 1 Januari 2010, seiring dengan waktunyapun maka earmarking tax mulai diterapkan di Indonesia. Dengan adanya otonomi daerah ini, urusan pemerintahan yang dulunya berpusat dan menjadi kewenangan dari pemerintah pusat, saat ini melalui pelaksanaan otonomi daerah kewenangan tersebut telah diserahkan kepada pemerintah daerah. Tujuan dari otonomi daerah ini juga telah disampaikan dalam Undang-Undang Nomor 32 Tahun 2004, pasal 2 ayat 3 yang mengatakan bahwa pemerintah daerah sebagaimana dimaksud pada ayat 2 menjalankan otonomi seluasluasnya, kecuali urusan pemerintahan yang menjadi urusan pemerintah, dengan tujuan meningkatkan kesejahteraan masyarakat, pelayanan umum, dan daya saing daerah.Sejak tanggal 1 Januari 2010 hingga saat ini undang-undang tersebut digantikan oleh UndangUndang Republik Indonesia Nomor 28 Tahun 2009 yang mengatur mengenai pajak daerah 
dan retribusi daerah. Salah satu yang menjadi hal baru dan tidak diatur dalam undang-undang sebelumnya adalah mengenai alokasi dari beberapa pajak daerah. Sebagian hasil penerimaan pajak dialokasikan untuk membiayai kegiatan yang berkaitan dengan pajak tersebut. Kebijakan desentralisasi fiskal tersebut merupakan dukungan kepada pemerintah daerah untuk pelayanan publik diwujudkan dengan mentransfer dana ke daerah sesuai dengan peraturan perundang-undangan yang berlaku, dalam hal ini yaitu Undang-Undang Nomor 28 Tahun 2009 tentang Pajak Daerah dan Retribusi Daerah. Melalui peraturan perundangan tersebut diharapkan daerah dapat lebih mendorong peningkatan pelayanan kepada masyarakat dan kemandirian daerah.

Earmarking tax merupakan pengalokasian dana bagihasil pajak yang sudah jelas peruntukannya, earmarking tax mengalokasikan sejumlah penerimaan pajak untuk mendanai sektor yang berkaitan dengan pajak yang dipungut. Dalam hal ini earmarking tax memberikan kemudahan bagi masyarakat umum untuk dapat mengetahui manfaat dari pajak seperti hasil dana pajak rokok yang diperuntukan untuk pelayanan kesehatan masyarakat. Dengan demikian dapat dilihat dampak dari earmarking tax sangat besar, earmarking tax bisa membantu suatu program untuk bisa berjalan dengan baik dikarenakan pemungutan pajak yang dipungut akan dialokasikan untuk membiayai program yang berkaitan dengan pajak yang dipungut.

Dalam rangka pelaksanaan pemungutan pajak rokok, Direktorat Jenderal Perimbangan Keuangan bersama dengan Direktorat Jenderal Bea dan Cukai dan Direktorat Jenderal Perbendaharaan telah melakukan sosialisasi kebijakan pajak rokok kepada pejabat dispenda provinsi, pengusaha/pengelola pabrik rokok dan importir rokok, dan pejabat dari Kantor Pelayanan Bea dan Cukai. Dalam teori kebijakan publik, efisiensi penggunaan anggaran bagi pemerintah adalah hal yang penting. Salah satu langkah untuk dapat mencapai tujuan dalam mensejahterakan masyarakat dalam anggaran pemerintah menurut ekonomi adalah melalui earmarking tax, yaitu kebijakan pemerintah dalam menggunakan anggaran yang sumber penerimaan maupun program pengeluarannya akan secara spesifik ditentukan peruntukkannya.Melihat fakta yang sudah dijelaskan tersebut, maka dalam kajian ini pendekatan yang dilakukan adalah dengan mengkaji kemungkinan penerapan earmarking tax atas pajak rokok di Kota Tomohon yang dilihat dari aspek legalitas hukum dan landasan dasar (seperti asas manfaat) serta memakai jenis belanja yang dapat diearmarking dengan asumsi-asumsi yang telah ditetapkan peruntuannya.Harapannya, dengan diterapkannnya earmarking tax yang paling sesuai dengan keadaan ekonomi maupun sosial lainnya di Tomohon, akan tercipta suatu efisiensi penggunaan anggaran yang lebih bermanfaat bagi publik.

Kota Tomohon telah menjadi kota yang menerima dana bagi hasil pajak rokok dalam kata lain kota Tomohon telah menerapkan earmarking tax pajak rokok yang diperuntukan untuk pelayanan kesehatan masyarakat dan penegakan hukum yang berkaitan dengan rokok. Earmarking tax menjadikan sumber dana dan pembiayaannya terarah. Dengan demikian manfaatnya akan terlihat jelas meskipun masi banyak masyarakat yang masi belum mengetahui sumber dana dari setiap pembiayaan dan peruntukannya namun earmarking tax yang diterapkan di Kota Tomohon mempermudah pemerintah dalam mengalokasikan dana karna didasari oleh peraturan perundang-undangan.

\section{TINJAUAN PUSTAKA}

Konsep Akuntansi. Menurut Hendra (2014), Akuntansi adalah seperangkat pengetahuan dan fungsi yang berkepentingan dengan masalah pengadaan, pengesahan, pencatatan, pengklasifikasian, pemrosesan, peringkasan, penganalisisan, penginterprestasian, dan penyajian secara sistematik informasi yang dapat dipercaya dan berdaya guna tentang transaksi dan kejadian yang bersifat keuangan yang diperlukan dalam pengelolaan dan 
pengoperasian suatu unit usaha dan yang diperlukan untuk dasar peyusunan pelaporan yang harus disampaikan untuk memenuhi pertanggungjawaban pengurusan keuangan dan lainnya.

Konsep Perpajakan. Menurut Soemitro dalam Resmi (2014), Pajak adalah iuran rakyat kepada kas negara berdasarkan undang-undang (yang dapat dipaksakan) dengan tidak mendapat jasa timbal balik (kontraprestasi) yang langsung dapat ditunjukan, dan yang digunakan untuk membayar pengeluaran umum.

Akuntansi Perpajakan. Menurut Supriyanto (2011),Akuntansi perpajakan adalah suatu proses pencatatan, penggolongan, dan pengiktisaran suatu transaksi keuangan kaitannya dengan kewajiban perpajakan dan diakhiri dengan pembuatan laporan keuangan fiskal sesuai dengan ketentuan dan peraturan perpajakan yang terkait sebagai dasar pembuatan surat pemberitahuan.

Fungsi Akuntansi Perpajakan. Menurut Rasmi (2014), fungsi akuntansi perpajakan adalah mengolah data kuantitatif yang akan digunakan untuk menyajikan keputusan, oleh sebab itu maka akuntansi harus memenuhi tujuan kualitatif. Adapun fungsi akuntansi perpajakan adalah mengolah data kuantitatif yang akan digunakan untuk menyajikan laporan keuangan yang memuat perhitungan perpajakan.

Pajak Daerah. Menurut Rani (2017), pajak daerah bermakna bahwa pajak daerah sesungguhnya dipungut, dikumpulkan, ditentukan tarif dan wajib pajaknya oleh pemerintah daerah setempat.

Pengalokasian Dana Pajak (Earmarking Tax). Menurut Almaghfi (2016), earmarking tax adalah beberapa pajak yang sengaja dipisahkan dari pendapatan secara keseluruhan dan hanya bisa digunakan untuk program-program khusus pemerintah dan digunakan sepenuhnya untuk program tersebut.

Pengertian Earmarking Tax. Menurut Clague dan Gordon (1939) yang dikutib oleh Almaghfi (2016), earmarking tax adalah kontraprestasi yang sesuai peruntukannya dan harus ditentukan dalam undang-undang maupun peraturan pelaksanaannya (Perda), sehingga terdapat kepastian mengenai adanya kewajiban kontraprestasi berupa pelayanan jenis pajak bersangkutan.

Jenis-jenis Earmarking Tax. Menurut Bird dan Jung (2005: 7) yang dikutip oleh (Tambing, 2017), berdasarkan jenisnya earmarking tax ini bisa dibagi menjadi dua yaitu :

a. Substantive earmarking tax adalah praktik mengaitkan dengan kuat antara sumber dana dengan pengeluarannya. Jika dana yang diterima meningkat maka pengeluaran juga akan meningkat proposional dengan peningkatan tersebut;

b. Symbolic earmarking tax di lain sisi adalah praktik mengaitkan sumber dana dengan pengeluaran dengan aturan yang longgar, sehingga proporsi terhadap pengeluaran dana tersebut untuk pos pengeluaran yang telah di earmarking tax tergantung dari pengambil kebijakan.

Earmarking Tax Pajak Rokok. Menurut Undang-Undang Nomor 28 Tahun 2009, Pajak rokok adalah pungutan atas cukai rokok yang dipungut oleh instansi pemerintah yang berwenang memungut cukai bersamaan dengan pemungutan cukai rokok. Tarif pemungutan pajak rokok dikenakan sebesar $10 \%$ dan pada pasal 31 penerimaan pajak rokok, baik bagian provinsi maupun bagian kabupaten/kota, dialokasikan paling sedikit 50\% untuk mendanai pelayanan kesehatan masyarakat dan penegakan hukum oleh aparat yang berwenang.

\section{METODE PENELITIAN}

3.1 Jenis Penelitian. Jenis penelitian yang digunakan yaitu penelitian kualitatif dengan pendekatan analisis deskriptif. Penelitian kualitatif sebagai prosedur penelitian yang menghasilkan data deskriptif berupa kata-kata atau lisan dari orang-orang dan perilaku yang diamati dari fenomena yang terjadi. Penelitian ini memberikan penggambaran secara sistematis mengenai unsur-unsur yang relevan melalui pandangan seseorang, organisasi, atau 
lainnya.

3.2 Sumber Data. Sumber data yang digunakan dalam penelitian ini adalah data primer yaitu data yang langsung dari objek penelitian atau tempat penelitian berupa data dan informasi yang relevan dengan penelitian, lewat wawancara langsung dengan pihak terkait yaitu kepala bidang bagian pajak di Dinas Pendapatan Pengelolaan Keuangan dan Barang Milik Daerah Kota Tomohon dan mengambil data dana bagihasil pajak rokok serta jumlah realisasi dan peraturan yang berkaitan dengan penerimaan dana bagi hasil pajak rokok dan pengalokasiannya.

\section{Metode Pengumpulan data}

a. Wawancara adalah teknik pengumpulan data dengan cara melakukan kegiatan komunikasi langsung seperti tanya jawab sambil tatap muka dengan pihak terkait yaitu kepala bidang pajak Dinas Pendapatan dan Pengelolaan Keuangan dan Barang Milik Daerah Kota Tomohon. Dengan maksud membahas tentang penerapan earmarking tax untuk mendapatkan informasi yang akurat.

b. Dokumentasi merupakan cara pengumpulan data dengan menggunakan arsip atau dokumen-dokumen yang bersifat tulisan dari instansi yang bersangkutan berhubungan dengan penerimaan dana bagi hasil pajak rokok dan kebijakan pengalokasian dana bagi hasil earmarking tax atas pajak rokok dari pihak terkait di Dinas Pendapatan dan Pengelolaan Keuangan dan Barang Milik Daerah Kota Tomohon.

3.3 Metode dan Proses Analisis. Metode analisis yang digunakan adalah metode analisis deskriptif kualitatif, yaitu suatu metode pembahasan yang sifatnya menguraikan, menggambarkan, membandingkan, dan menerangkan suatu data atau keadaan yang bertujuan untuk mendapatkan gambaran yang lebih jelas dan terperinci mengenai suatu keadaan berdasarkan informasi yang telah diperoleh kemudian dikumpulkan sehingga mendapat informasi yang diperlukan untuk menganalisa masalah yang ada.

\section{HASIL PENELITIAN DAN PEMBAHASAN}

\subsection{Hasil Penelitian}

Pengaturan Alokasi Dana Pajak Rokok. Penetapan pajak rokok sebagai salah satu pajak daerah didasarkan pada pertimbangan mengendalikan konsumsi rokok, mengendalikan peredaran rokok ilegal, serta melindungi masyarakat atas dampak negatif rokok dan peningkatan pendanaan fungsi pelayanan kesehatan masyarakat serta untuk meningkatkan PAD. Pajak rokok yang dikenakan sebesar $10 \%$ dari cukai rokok dimaksudkan juga untuk memberikan peran yang optimal kepada pemerintah daerah untuk dapat mengoptimalkan peruntukkan dana bagi hasil pajak rokok untuk pelayanan kesehatan masyarakat.

Tata Cara Perhitungan Dana Bagi Hasil. Pajak rokok yang dipungut dari pemerintah disetor ke rekening kas umum daerah provinsi secara proporsional berdasarkan jumlah penduduk. Peraturan Gubernur Sulawesi Utara Tahun 2017 Pasal 2 ayat 5 menyatakan pembagian dari hasil penerimaan pajak rokok, diberikan kepada pemerintah kabupaten/kota dengan porsi sebesar 70\% untuk kabupaten/kota, sisanya sebesar 30\% diperuntukan bagi pemerintah provinsi. Dalam Peraturan Menteri Keuangan Republik Indonesia Nomor 102/PMK/07/2015 Pasal 31A menyatakan bahwa penerimaan pajak rokok, baik bagian provinsi maupun bagian kabupaten/kota, dialokasikan paling sedikit 50\% digunakan untuk mendanai pelayanan kesehatan masyarakat dan penegakan hukum oleh aparat yang berwenang.

Penyetoran Pajak Rokok. Dasar pengenaan pajak rokok adalah cukai rokok yang ditetapkan oleh pemerintah. Tarif pajak rokok ditetapkan sebesar 10\%, besaran pajak rokok terutang $=$ (tarif pajak $\mathrm{x}$ dasar pengenaan pajak rokok). Wajib pajak menghitung sendiri pajak rokok melalui Surat Pemberitahuan Pajak Rokok (SPPR). Pemungutan pajak rokok dilakukan oleh kantor bea dan cukai (KPBC) bersamaan dengan pemungutan cukai rokok, apa bila WP 
tidak melakukan pembayaran pajak rokok, KPBC tidak melayani permohonan pemesanan pita cukai hasil tembakau.Pajak rokok disetorkan oleh direktur pajak daerah dan retribusi daerah sebagai KPA ke RKUD Provinsi setiap triwulan pada bulan berikutnya. Penyetoran pajak rokok ke masing-masing provinsi dilakukan secara proporsional menurut jumlah penduduk dan realisasi penerimaan pajak rokok. KPA menerbitkan surat ketetapan penyetoran pajak rokok (SKP-PR) dalam rangkap 3 dengan peruntukan lembar ke-1 untuk KPPN Jakarta, lembar ke-2 untuk PPK, dan lembar ke-3 untuk pertanggal. PPK menerbitkan surat permintaan pembayaran pajak rokok (SPP-PR) untuk penyetoran pajak rokok ke RKUD provinsi. PPK menyampaikan SPP-PR ke PPSPM dilampiri SKP-PR, kemudian PPSPM melakukan pengujian terhadap SPP-PR beserta lampirannya. Apabila telah sesuai maka PPSPM akan menerbitkan surat perintah membayar pajak rokok (SPM-PR) dalam rangkap 3 yaitu lembar ke-1 dan ke-2 untuk KPPN Jakarta lembar ke-3 untuk pertinggal. Selanjutnya KPPN Jakarta II akan menerbitkan surat perintah pencairan dana (SP2D), kemudian KPA memberitahukan penyetoran pajak rokok kepada Gubernur paling lambat 2 hari kerja setelah SP2D penyetoran pajak rokok diterbitkan.

Penerimaan Dana Bagi Hasil Pajak Rokok. Alokasi dana bagi hasil pajak provinsi kepada pemerintah kabupaten/kota dari pajak rokok tahun anggaran 2017 sebesar Rp104.340.488.323 dengan pembagian sesuai dengan jumlah penduduk dari setiap kabupaten/kota masing-masing, dan alokasi dana bagi hasil pajak rokok yang diterima kota Tomohon ditahun 2017 sebesar Rp4.280.894.654. Peraturan Gubernur Sulawesi Utara Nomor 4 Tahun 2017 Pasal 5 menyatakan khusus pajak rokok dihitung per triwulan sesuai dengan yang ditransfer oleh pemerintah pusat. Untuk triwulan IV yang ditransfer adalah bulan Oktober dan November sedangkan untuk bulan Desember disalurkan bersamaan dengan triwulan I tahun berikutnya.

Tabel 1. Penerimaan pajak rokok kota Tomohon

\begin{tabular}{|c|c|c|c|c|}
\hline No & Uraian & Tanggal & $\begin{array}{c}\text { Jumlah } \\
\text { Penetapan } \\
\text { (Rp) }\end{array}$ & $\begin{array}{c}\text { Jumlah } \\
\text { Penerimaan } \\
(\mathbf{R p})\end{array}$ \\
\hline 1 & Triwulan I TA 2017 & $7 / 6 / 2017$ & 145.814 .060 & 145.814 .060 \\
\hline 2 & Triwulan II TA 2017 & $6 / 9 / 2017$ & 1.094.018.006 & 1.094.018.006 \\
\hline 3 & Triwulan III TA 2017 & $14 / 11 / 2017$ & 1.017.508.125 & 1.017.508.125 \\
\hline 4 & $\begin{array}{l}\text { Triwulan IV TA } 2017 \\
\text { (Oktober dan November) }\end{array}$ & $21 / 12 / 2017$ & 815.806 .390 & 815.806 .390 \\
\hline 5 & $\begin{array}{l}\text { Triwulan IV TA } 2017 \\
\text { (Desember) }\end{array}$ & $3 / 5 / 2018$ & 1.207 .748 .073 & 1.207 .748 .073 \\
\hline & TOTAL & & 4.280.894.654 & 4.280.894.654 \\
\hline
\end{tabular}

Sumber: Dinas Pendapatan Pengelolaan Keuangan dan Barang Milik Daerah Kota Tomohon, 2017.

Dari tabel 1 memperlihatkan penerimaan dana bagi hasil pajak rokok yang diterima kota tomohon sering terjadi keterlambatan hal ini menyebabkan terjadi keterlambatan dalam melaksanakan program yang sudah dianggarkan dan direncanakan terlebih dalam pelayanan kesehatan masyarakat. Menurut Undang-Undang Nomor 28 Tahun 2009 mengatakan bahwa penerimaan dana bagi hasil pajak rokok dialokasikan paling sedikit 50\% untuk dinas kesehatan masyarakat dan penegakan hukum, namun tidak semua program kesehatan masyarakat ditanggung dari dana bagi hasil pajak rokok melainkan hanya program kesehatan masyarakat yang bersifat promosi, preventif, dan kuratif. Dengan demikian berikut ini merupakan jumlah pengeluaran untuk pendanaan upaya kesehatan masyarakat di Kota Tomohon tahun 2017 yang dilihat dari kebutuhan daerah Kota Tomohon tersebut: 
Tabel 2. Pengeluaran belanja untuk program kesehatan masyarakat kota tomohon 2017

\begin{tabular}{|c|c|c|c|}
\hline No & Program & Kegiatan & $\begin{array}{l}\text { Jumlah Dana } \\
\text { (Rp) }\end{array}$ \\
\hline 1 & $\begin{array}{l}\text { Promosi Kesehatan dan } \\
\text { Pemberdayaan Masyarakat }\end{array}$ & $\begin{array}{l}\text { Pengembangan Media Promosi dan } \\
\text { Informasi Hidup Sehat }\end{array}$ & 37.800 .000 \\
\hline 2 & $\begin{array}{l}\text { Promosi Kesehatan dan } \\
\text { Pemberdayaan Masyarakat }\end{array}$ & Penyuluhan Masyarakat Pola Hidup Sehat & 61.314 .600 \\
\hline 3 & $\begin{array}{l}\text { Promosi Kesehatan dan } \\
\text { Pemberdayaan Masyarakat }\end{array}$ & $\begin{array}{l}\text { Peningkatan Pendidikan Tenaga Penyuluh } \\
\text { Kesehatan }\end{array}$ & 35.630 .800 \\
\hline 4 & $\begin{array}{l}\text { Pencegahan dan Penanggulangan } \\
\text { Penyakit Menular }\end{array}$ & $\begin{array}{l}\text { Peningkatan Survellance Epidemiologi dan } \\
\text { Penanggulangan Wabah }\end{array}$ & 95.173 .500 \\
\hline 5 & $\begin{array}{l}\text { Peningkatan Pelayanan } \\
\text { Kesehatan Lansia } \\
\text { Pendampingan Perencanaan }\end{array}$ & Pelayanan Pemeliharaan Kesehatan & 89.358 .700 \\
\hline 6 & $\begin{array}{l}\text { Persalinan dan Pencegahan } \\
\text { Komplikasi }\end{array}$ & Pelatihan Kader P4K & 584.332 .500 \\
\hline 7 & $\begin{array}{l}\text { Pencegahan dan Penanggulangan } \\
\text { Penyakit Menular }\end{array}$ & $\begin{array}{l}\text { Pelayanan dan Pencegahan Penyakit Tidak } \\
\text { Menular }\end{array}$ & 40.323 .000 \\
\hline 8 & Kesehatan Jiwa & $\begin{array}{l}\text { Penyuluhan dan Peran Serta Masyarakat } \\
\text { Kesehatan Jiwa }\end{array}$ & 57.234 .200 \\
\hline 9 & Kesehatan Olahraga & Kegiatan Kesehatan Olahraga Terpadu & 86.916 .000 \\
\hline 10 & $\begin{array}{l}\text { Program Upaya Kesehatan } \\
\text { Masyarakat }\end{array}$ & $\begin{array}{l}\text { Peningkatan Pelayanan dan Penanggulangan } \\
\text { Masalah Kesehatan }\end{array}$ & 236.254 .000 \\
\hline 11 & $\begin{array}{l}\text { Program Upaya Kesehatan } \\
\text { Masyarakat }\end{array}$ & $\begin{array}{l}\text { Pembanguan Fasilitas Publik (Smoking } \\
\text { Area) Di Kantor }\end{array}$ & 640.000 .000 \\
\hline 12 & $\begin{array}{l}\text { Program Perbaikan Gizi } \\
\text { Masyarakat }\end{array}$ & $\begin{array}{l}\text { Penanggulangan Kurang Energi Protein } \\
\text { (KEP), Anemia Gizi Besi, Gangguan Akibat } \\
\text { Kurang Yudium (GAKY), Kurang Vitamin } \\
\text { A dan Kekurangan Zat Gizi Mikro Lainnya } \\
\text { TAL }\end{array}$ & 2.392.552.300 \\
\hline
\end{tabular}

Tabel 2 menunjukkan besarnya realisasi dana yang telah tersalur untuk pendanaan upaya kesehatan masyarakat yang telah terealisasi di tahun 2017. Dengan anggaran yang telah ditetapkan yaitu sebesar Rp2.392.552.300,00adapun sebagian anggaran dialokasikan untuk membangun infrastruktur kawasan bebas rokok serta melakukan renovasi dalam pembangunan puskesmas, serta dalam mensosialisasikan bahaya rokok ditengah masyarakat.

\subsection{Pembahasan}

Analisis Pengaturan Alokasi Dana Bagi Hasil Pajak Rokok Pada Dinas Pendapatan Pengelolaan Keuangan dan Barang Milik Daerah KotaTomohon. Pengalokasian dana pajak rokok atau earmarking taxpajak rokok minimal 50\% harus dialokasikan dananya untuk upaya kesehatan masyarakat, adapun dana pajak rokok yang telah ditransfer langsung dinyatakan sebagai pendapatan asli daerah. Keberadaan besaran minimal 50\% ini diatur dalam Peraturan Gubernur Sulawesi Utara Nomor 4 Tahun 2017, sehingga dijadikan sebagai jaminan bagi ketersediaan dana untuk peningkatan upaya kesehatan masyarakat, namun pembiayaan untuk pengeluaran tersebut juga didasarkan atas keperluan dari daerah, sehingga nominal yang harus dialokasikan bisa lebih. Adapun jika didapati realisasi anggaran lebih dari target Rp1.887.874.542 dari Rp4.275.651.655 anggaran yang telah ditetapkan (mencapai 50\%) maka dalam Peraturan Gubernur Sulawesi Utara Nomor 36 tahun 2016 tentang selisih kurang atau lebih bagi hasil pajak provinsi kepada pemeritah kabupaten kota menyatakan 
pada pasal 5 ayat 2 jika telah melaporkan selisih kurang atau lebih dari anggaran yang telah direalisasi maka akan diperhitungkan di tahun yang berikutnya.

Penerimaan Pajak Rokok Provinsi Sulawesi Utara dan Belanja Untuk Pendanaan Upaya Kesehatan Masyarakat. Penggunaan pajak rokok untuk pendanaan pelayanan kesehatan masyarakat digunakan untuk kegiatan, penurunan faktor risiko penyakit tidak menular, peningkatan promosi kesehatan, peningkatan kesehatan keluarga, peningkatan kesehatan lingkungan, peningkatan kesehatan kerja dan olah raga, peningkatan pengendalian konsumsi rokok dan produk tembakau lainnya, dan pelayanan kesehatan difasilitasi kesehatan tingkat pertama. Selain digunakan untuk kegiatan sebagaimana dimaksud, pajak rokok dapat digunakan untuk peningkatan pembangunan dan pemeliharaan gedung Pusat Kesehatan Masyarakat (PUSKESMAS). Dalam "Panduan Umum Penggunaan Pajak Rokok untuk bidang Kesehatan", upaya kesehatan masyarakat yang dimaksud yaitu pengendalian konsumsi rokok dan produk tembakau lainnya, penegakan hukum dalam kebijakan kawasan bebas rokok, memberantasrokok ilegal, dan upaya kesehatan masyarakat. Alokasi dana bagi hasil pajak rokok untuk kesehatan diharapkan dapat mengisi kekurangan di luar belanja rutin daerah. Sesuai dengan hasil penelitian diatas, maka jumlah realisasi penerimaan dan dana bagi hasil pajak rokok serta jumlah belanja dalam mendanai upaya kesehatan masyarakat di Kota Tomohon tahun 2015 - 2018 sebagai berikut :

Tabel 3. Hasil realisasi dana

\begin{tabular}{|c|c|c|c|c|}
\hline Keterangan & 2015 & 2016 & 2017 & 2018 \\
\hline Dana & & & & \\
\hline Hasil Pajak & & & & \\
\hline Rokok Kota & Rp3.876.955.157 & Rp3.322.353.492 & Rp4.280.894.654 & Rp4.275.651.655 \\
\hline Tomohon Yang & & & & \\
\hline Diterima & & & & \\
\hline $\begin{array}{l}\text { (Earmarking } \\
\text { tax) } 50 \%\end{array}$ & Rp2.093.555.785 & Rp1.814.005.007 & Rp2.393.020.112 & Rp2.394.364.927 \\
\hline Pengeluaran & & & & \\
\hline $\begin{array}{l}\text { Untuk Program } \\
\text { Kesehatan }\end{array}$ & Rp1.783.399.372 & Rp1.508.348.485 & Rp1.887.874.542 & Rp1.881.286.728 \\
\hline
\end{tabular}

Sumber: Tomohon dalam angka, 2015-2018.

Tabel 3 menunjukkan bahwa besaran pengeluaran untuk belanja dalam hal upaya kesehatan masyarakat. Untuk tahun 2015 adalah senilai Rp2.093.555.785. Dana yang digunakan untuk belanja upaya kesehatan masyarakat perhitungannya sebagai berikut :

Presentase $(\%)=(\mathrm{Rp} 2.093 .555 .785: \mathrm{Rp} 3.876 .555 .157) \times 100 \%$

$$
=54 \%
$$

Untuk tahun 2016 adalah senilai Rp3.322.353.492. Dana yang digunakan untuk belanja upaya kesehatan masyarakat perhitungannya sebagai berikut :

Presentase $(\%)=(\mathrm{Rp} 1.814 .005 .007: \mathrm{Rp} 3.322 .353 .492) \times 100 \%$

$$
=54,6 \%
$$

Untuk tahun 2017 adalah senilai Rp2.392.552.300,00. Dana yang digunakan untuk belanja upaya kesehatan masyarakat perhitungannya sebagai berikut :

Presentase $(\%)=(\operatorname{Rp} 2.392 .552 .300: \operatorname{Rp} 4.280 .894 .654) \times 100 \%$ $=55,9 \%$

Untuk tahun 2018 adalah senilai Rp4.275.651.655. Dana yang digunakan untuk belanja upaya kesehatan masyarakat perhitungannya sebagai berikut :

Presentase $(\%)=(\operatorname{Rp} 2.394 .364 .927: \mathrm{Rp} 4.275 .651 .655) \times 100 \%$ 
$=56 \%$

Dengan demikian, pengeluaran Dinas Pendapatan Keuangan dan Pengelolaan Barang Milik Daerah Kota Tomohon untuk upaya kesehatan masyarakat pada tahun 2015 adalah sebesar 54\%, tahun 2016 sebesar 54,6\%, tahun 2017 sebesar 55,9\% dan tahun 2018 sebesar $56 \%$ dari dana bagi hasil pajak rokok yang diterima Kota Tomohon, adapun sebagian dana disalurkan kebagian penegakan hukum. Untuk itu, perbandingan antara alokasi dana pajak rokok dan belanja yang dilakukan Dinas Kesehatan Kota Tomohon telah sesuai dengan peraturan yang diterapkan, karena Dinas Kesehatan Kota Tomohon sudah memaksimalkan belanja dalam menggunakan dana alokasi dari penerimaan pajak rokok provinsi. Prosentase di atas juga menunjukan bahwa Kota Tomohon telah melaksanakan pengalokasian dana bagi hasil pajak rokok dengan tepat karena total earmarking tax yang digunakan untuk upaya kesehatan masyarakat telah melebihi $50 \%$ yang telah menjadi ketetapannya yang ada di dalam Undang - Undang Nomor 28 Tahun 2009.

\section{KESIMPULAN DAN SARAN}

\subsection{Kesimpulan}

Berdasarkan pembahasan dari hasil penelitian terhadap earmarking tax pajak rokok di

Kota Tomohon, maka dapat disimpulkan sebagai berikut :

1. Dana bagi hasil pajak rokok yang diterima kota Tomohon telah ditetapkan pengalokasian dananya sesuai dengan Undang-Undang Nomor 28 Tahun 2009 yaitu paling sedikit 50\% mendanai pelayanan kesehatan masyarakat dan penegakan hukum oleh aparat yang berwenang. Adapun Kota Tomohon sudah menerapkan pengalokasian dana pajak rokok untuk mendanai program kesehatan masyarakat hanya saja tidak semua program upaya kesehatan masyarakat ditanggung oleh dana bagi hasil pajak rokok hanya yang bersifat promotif, preventif, dan kuratif.

2. Dana bagi hasil pajak rokok yang diterima Kota Tomohon bukan hanya untuk membiayai pelayanan kesehatan masyarakat tapi juga untuk penegakan hukum yang berwenang untuk melakukan kegiatan yang bersangkutan dengan rokok. Program tersebut seperti kegiatan memberantas bahaya rokok terlebih dalam memberantas rokok ilegal yang tidak memiliki lekatan pita cukai serta sosialisasi tentang upaya dalam membangkitkan kesadaran masyarakat akan dampak bahaya rokok dan cara mengenal rokok legal dan ilegal.

3. Berdasarkan realisasi belanja yang dilakukan Kota Tomohon, kebijakan earmarking tax dari penerimaan pajak rokok sudah diterapkan sesuai dengan peraturan yang berlaku. Hal ini dikarenakan belanja untuk upaya kesehatan masyarakat telah mencapai nilai minimalnya bahkan melebihi nilai besarannya yaitu sebesar Rp2.140.447.327,00 sementara alokasi dana pajak rokok direalisasikan untuk pelayanan kesehatan masyarakat sebesar Rp2.392.552.300,00 atau 55,9\% dari total penerimaan dana bagi hasil pajak rokok yang diterima Kota Tomohon tahun 2017 begitu juga dengan tahun sebelum dan sesudahnya telah mencapai besaran yang sesuai dengan yang menjadi ketetapan. Dengan data yang ada menunjukan bahwa Kota Tomohon telah mengalokasikan dana bagi hasil pajak rokok sesuai dengan ketentuan yang berlaku bahkan setiap tahun mengalami peningkatan yang sangat baik.

\subsection{Saran}

Berdasarkan penelitian yang dilakukan ini, penulis menyarankan agar Kota Tomohon lebih memerhatikan ketentuan yang ada didalam Undang-Undang Nomor 28 Tahun 2009 yang mengatur tentang pengalokasian dana bagi hasil pajak rokok. Serta untuk pemerintah pusat sebaiknya mentransfer dana bagi hasil pajak rokok tepat waktu agar tidak terjadi keterlambatan dalam menjalankan realisasi program upaya kesehatan masyarakat yang telah ditetapkan, dan juga untuk pemerintah dibagian provinsi memperhatikan anggaran yang akan 
dibagihasilkan agar bisa mencegah selisih kurang di kabupaten/kota. Dan saran penulis untuk Dinas Pendapatan Pengelolaan Keuangan dan Barang Milik Daerah Kota Tomohon yaitu dapat meningkatkan dana yang diterima agar dapat meningkatkan dana pengalokasian untuk mendanai program upaya hidup sehat masyarakat serta penegakan hukum demi kenyamanan masyarakat terlebih dalam rangka mengurangi bahaya rokok ditengah masyarakat, dan memperhatikan program yang berkaitan dengan pemberantasan rokok ilegal yang tidak memiliki lekatan cukai rokok untuk ditingkatkan serta meningkatkan program dalam mensosialisasikan bahaya rokok atau meningkatkan kesadaran akan bahaya rokok, serta perlu menjaga kestabilan realisasi agar mencegah terjadi penurunan penerimaan dana bagi hasil pajak rokok.

\section{DAFTAR PUSTAKA}

Almaghfi, L. B. (2016). Studi Pemikiran Penerapan Tax Earmarking Pada Bea Perolehan Hak Atas Tanah dan Bangunan (BPHTB) Di Kota Malang. SKRIPSI Universitas Brawijaya. Malang. http://perpajakan.studentjournal.ub.ac.id/index.php/perpajakan/article/view/246. 11 Agustus 2018.

Fitriastuti, S. M. (2014). Studi Penerapan Earmarking Tax Pajak Kendaraan Bermotor Terkait Pemeliharaan Jalan Di Provinsi Jawa Timur. SKRIPSI-Universitas Brawijya. Malang.https://jimfeb.ub.ac.id/index.php/jimfeb/article/view/1438. 27 Agustus 2018.

Hendra. (2014). Penerapan Akuntansi Pajak Penghasilan Pasal 23 Pada PT. Golden Mitra Inti Perkasa. Jurnal EMBA. Vol. 2 No. 1 Issn 2303-1174. https://ejournal.unsrat.ac.id/index.php/emba/article/download $\quad$ /3513/3042. 12 September 2018.

Peraturan Gubernur Sulawesi Utara Nomor 4 Tahun 2017. Tentang Pedoman Pelaksanaan Dana Bagi Hasil Pajak Provinsi Kepada Pemerintah Kabupaten/Kota.

Peraturan Gubernur Sulawesi Utara Nomor 16 Tahun 2016. Tentang Penetapan Alokasi Sementara Bagi Hasil Pajak Provinsi Kepada Pemerintah Kabupaten/Kota SeProvinsi Sulawesi Utara dari Pajak Rokok.

Peraturan Gubernur Sulawesi Utara Nomor 36 tahun 2016. Tentang Selisi Kurang Bagi Hasil Pajak Provinsi Kepada Pemeritah Kabupaten Kota.

Peraturan Menteri Keuangan Republik IndonesiaNomor 115/PMK.07/2013. Tentang Tata Cara Pemungutan Dan Penyetoran Pajak Rokok.

Peraturan Menteri Keuangan Republik Indonesia Nomor 102/PMK.07/2015. Tentang Tata Cara Pemungutan dan Penyetoran Pajak Rokok. Perubahan Atas Peraturan Menteri KeuanganNomor 115/Pmk.07/2013.

Permana, Y.A. (2016). Pelaksanaan Pemungutan Pajak Rokok di Provinsi Lampung.SKRIPSI Bagian Hukum Administrasi Negara Fakultas Hukum Universitas Lampung. Lampung. $\quad$ http://digilib.unila.ac.id/ 23907/12/SKRIPSI\%20TANPA\%20BAB\%20PEMBAHASAN.pdf. 16 Agustus 2018.

Rani, R. (2017). Ciri-ciri Pajak Daerah. Pengertian Pajak Daerah. https://www.onlinepajak.com/pajak-daerah. 09 November 2018.

Rasmi, G. (2014). Akuntansi Pajak. https://rasmigracia.wordpress.com/2014/09/04/akuntansiperpajakan. 04 September 2018.

Resmi, S. (2014). Perpajakan Teori dan Kasus. Edisi 8. Jakarta: Salemba Empat. https://pustaka.unand.ac.id/2016-04-11-15-04-06/resensi-buku/item/111-perpajakanteori-dan-kasus-edisi-8-buku-1. 05 September 2018. 
Supriyanto, E. (2011). Akuntansi Perpajakan. Yogyakarta; Graha Ilmu.

Tambing, D. R. (2017). Implementasi Pengalokasian Dana Pajak (Earmarking Tax) Dari Penerimaan Pajak Rokok Terhadap Upaya Kesehatan Masyarakat di Provinsi Sulawesi Utara. SKRIPSI Fakultas Ekonomi dan Bisnis Unversitas Sam Ratulangi. Manado.https://ejournal.unsrat.ac.id/ index.php/gc/article/download/17143/16690. 20 Agustus 2018.

Undang-Undang Republik Indonesia Nomor 28 Tahun 2009. Perubahan Kedua Atas UndangUndang Nomor 18 Tahun 1997 Tentang Pajak Daerah dan Retribusi Daerah.Lembaran Negara Republik Indonesia 5049. 